\title{
The Vienna Protocol and Reflections on Nazi Medicine: Murder à la Carte
}

\author{
Rabbi Joseph Polak
}

An historian of World War II Germany was asked, about whether there was a single ideological notion that proved to be the most influential in allowing the horrific evils of the Holocaust to take place. It is the very idea, derived from the Romantics, he wrote, that artists are entitled to live outside of morality. Hitler and others unquestionably saw themselves in this way. With this realization we have arrived at the reductio ad absurdum of this Romantic ethic: the Artist as Murderer. And it is because we believe that like artists, physicians occupy a higher sphere, that we have, in Holocaust times, the transformation of the physician, like the artist, into the murderer. Like the artist, who murders but does not do so with his own hand, the physician supervises executions and unspeakable experiments. Anatomists buttressed their collections at a range of German and Austrian universities, by placing orders from among the executed and about-to-be executed. It is this that I have in mind when I speak of "murder-a-la-carte." Pernkopf was one of these anatomists. Through the atlas he immortalizes the victims. Years later, a surgeon asks about the atlas and protocols for continued use, to benefit patients and educate, are created. The surgeon may well be rescuing the medical profession itself from its own historical sins of presumed unaccountability, of returning it to a human place where the dignity of the patient remains inviolable, and where the victims of medically inspired evil gaze out at us from the pages of the atlas, both as a blessing and as a warning.

OPEN ACCESS

\section{Artist As Murderer}

Permit me to begin with a discussion about some of the English Romantic poets: Byron, Shelley, Keats - the whole gang of richly gifted, larger-than-life personalities, to many of whom personal, moral constraint seemed unknown. Life has to be lived at its fullest, what is valued above all else is the explosion of emotion - the widening of the heart to what pulsates around you in the world. The experiences most sought are the ones that shatter physical and spiritual boundaries and bring one closer to transcendence. These men, living this way, produced some of the greatest literature the English language has known. Their work pushes us further, expands our sensibilities, and helps widen our appreciation of nature and humanity.

Unfailingly, many of these poets pushed their moral limits. What gave them license to do so was the conviction, current throughout Western Europe at the time, and perhaps still operative in some circles, that the artist is not subject to the laws of morality in the way everybody else is. Superb artists, like Lord Byron, where such behavior furthers his creativity, may sleep with his sister.

An historian of World War II Germany was asked, at the end of his career, about whether there was a single idea, a single ideological notion that proved to be the most influential in allowing the horrific evils of the Holocaust to take place.

It is this very idea, derived from the Romantics, he wrote - that artists are entitled to live outside of morality, and are not answerable for their behavior to the rest of society.

Hitler, Speer and several of their acolytes unquestionably saw and understood themselves in this way. It enabled them, they believed, to become some kind of higher species of creature, not answerable, and not accountable. Think artist-without-conscience, and unfortunately, you will understand Hitler. And with this realization, we have arrived at the reductio ad absurdum of this Romantic ethic: the Artist as Murderer. 


\section{Physician As Murderer}

Throughout most of the 20th Century, no member of Western society has been more venerated than has the physician. Men are these (certainly before and during the Holocaust years) who are profoundly educated, who are scientists, healers, easers of suffering, devoted to humanity and its care, appreciated for their seriousness and presumed integrity. Put on that white lab coat and those around you almost melt in appreciation and respect. The doctors, too, need not answer to others for their behavior. In their presumed unqualified devotion to healing and to the alleviation of pain, we are endlessly grateful for all their devotion and sacrifice. They are not imagined to exist on the same plane as the rest of us, and their moral lives are for them, and not us, to contemplate.

And it is because we believe that like artists, they occupy a higher sphere where they need answer only to themselves, that we have, in Holocaust times, the transformation of the physician, like the artist, into the murderer.

Like the artist, who murders but does not do so with his own hand, the physician supervises the execution of the club-footed children, of the dwarfs and the negroes, of the gay, of the mad, and of the infertile. He supervises the unspeakable experiments on twins and in women's wombs and men's lungs that are conducted without anesthesia and without precaution for infection. He sends samples, sometimes while their owners are still alive, of their anatomy for academic contemplation, to his colleagues and teachers, for the furtherance of science, which has become a higher value than the furtherance of life.

\section{Murder à la Carte}

And it is the anatomists, buttressing their collections at a range of German and Austrian university laboratories, who calmly place orders from the thousands of those executed by the civil courts for little more than dissent, and who likewise procure from among the hundreds of thousands of innocent men, women and children in the Camps, bodies, both alive and dead; an endless menu becomes available to them - of exotic anatomic samples for perverse, sinister and very specialized scientific perusal.
From these cadavers they arranged their teaching labs; one such professor is known to have placed orders to a concentration camp for them to kill specimens of specified gender, height, weight and/or disease for his collection - and it is him, that I have in mind when I speak of Murder a la Carte.

\section{Pernkopf}

Pernkopf was one of these anatomists, and using samples from the range of bodies I have just described, he created perhaps the most beautiful and functional anatomical atlas the medical world has seen.

And so when all else fails, I am asked, when the only way to get at the surgical information we need, is by turning to Pernkopf, may we (Yee et al. 2019b)? Is this not the employment of radical evil, of true murder a la carte, in the interests of the good? Are we not somehow extending, continuing, the disrespect of his victims by consulting their likenesses in his atlas? Do their objections to their presence in his albums not cry out to us from every page, even decades after their murders?

Shouldn't we locate every Pernkopf atlas on the planet, for that matter, and burn it so that its heritage of evil finally be stymied? Didn't Goering's daughter have her tubes tied so that her father's genes never again be replicated?

I approach the sacred texts of Jewish law with care and with terror. I know that while Pernkopf's collection is tuma - obscene, untouchable by any measure - the surgeon needing to consult its secrets is holy, her patient is holy, and the skills and processes of healing are holy. The surgeon, her staff, her students and the patient are partners with the Almighty, Who is surely present in the operating theater. The atlas must be used if it can heal the patient, I discover from the halachic texts, but every living person involved with such a case; patient, family, students, staff - must be told from whence these illustrations come, and why it was necessary to use them (Polak 2017). That, in the end, is not replicating Goering's genes; it may even be a little bit of immortalizing his victims.

In immortalizing the victims in this way, the surgeon may well be rescuing the medical profession itself from its own historical sins of presumed unaccountability, 
of returning it to a human place where the dignity of the patient remains inviolable, and where the victims of medically-inspired evil gaze out at us from the pages of the Atlas, both as a blessing and as a warning.

\section{זכור ("remember")}

\section{References}

Polak, J.A. 2017. The Vienna Protocol: for when Jewish or Possibly-Jewish Human Remains are Discovered. In: Seidelman, W.E., Elbaum, L., Hildebrandt, S. (Eds.),How to deal with Holocaust era human remains: Recommendations arising from a special symposium.Elie Wiesel Center for Jewish Studies, Boston University, Boston, MA. Accessed at: http://www.bu.edu/jewishstudies/files/2018/08/HOWTO-DEAL-WITH-HOLOCAUST-ERAREMAINS.FINAL_pdf

Yee A, Zubovic E, Yu J, Shuddhadeb R, Hildebrandt S, Seidelman WE., Polak JA., Grodin, MA, Coert H, Brown D, KodnerIJ, Mackinnon SE. 2019b. Ethical considerations in the use of Pernkopf's atlas of anatomy: A surgical case study. Surgery 165(5), 860-867.

\footnotetext{
About the Author

Rabbi Joseph Polak is a child survivor of the Holocaust. Born in The Hague, Netherlands, Rabbi Polak is a survivor of the Westerbork and Bergen-Belsen concentration camps. After the war and he and his mother lived in Montreal. Emeritus Director of the Hillel House at Boston University, Rabbi Polak is the Chief Justice of the Rabbinical Court of Massachusetts and an Associate Professor of Health Law at Boston University School of Public Health. Rabbi Polak worked in close collaboration with Dr. Michael Grodin of Boston University, with Dr. William Seidelman, Dr. Sabine Hildebrandt, and Dr. Susan Mackinnon, as well as other scholars, on aspects of Holocaust and medicine during the Shoah. Their efforts in the 2017 Special Symposium held at Yad Vashem (Jerusalem) resulted in the passing of the Vienna Protocol on the handling of modern-day discoveries of the remains of possible victims of the Holocaust and the use of the Pernkopf atlas.
}

\section{Rabbi Joseph Polak}

Chief Justice, Rabbinical Court of Boston, Massachusetts Associate Professor of Health Law

Boston University School of Public Health

Contact: RJP@bu.edu

\section{Licensing}

The author has chosen to license this content under a Creative Commons Attribution, NonCommercial, NoDerivatives 4.0 International License.

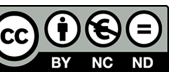

Authorization for publication of images from Pernkopf's atlas has been granted for use in this article only. The atlas images must remain within the context of this article for open-access, scholarship and educational use. The atlas images in this article may not be removed from this article, nor reproduced, nor distributed, outside of the context of this article, for scholarly, education or commercial purposes, without the expressed permission of the Josephinum.

\section{Conflict of Interest Statement}

The Journal of Biocommunication Management Board and Editors believe that transparency in academic research is essential. Our JBC authors are now required to disclose any possible conflict of interest when submitting a manuscript. In accordance with the Journal of Biocommunication's editorial policy, no potential conflict of interest has been reported or declared by this author. 